\title{
Adiponectin and Testosterone Levels and Their Correlations with Fertility in Anglo- Nubian x Etawah Grade Crossbred Bucks
}

\author{
Hafizuddin ${ }^{a}$, N. W. K. Karja ${ }^{\mathrm{b}}$, L. Praharani ${ }^{\mathrm{c}}$, \& M. A. Setiadi ${ }^{\mathrm{b}, *}$ \\ a Laboratory of Reproduction, Faculty of Veterinary Medicine, Universitas Syiah Kuala \\ Jalan Teungku Hasan Krueng Kalee No. 4, Kopelma Darussalam, Syiah Kuala, Banda Aceh 23111, Indonesia \\ bDivision of Reproduction and Obstetrics, Department of Veterinary Clinic, Reproduction, and Pathology, \\ Faculty of Veterinary Medicine, IPB University (Bogor Agricultural University) \\ Jalan Agatis, Kampus IPB Dramaga Bogor 16680, Indonesia \\ 'Research Institute for Animal Production \\ PO BOX 221-Bogor 16002, Indonesia \\ *Corresponding author: setiadi03@yahoo.com \\ (Received 04-10-2019; Revised 04-02-2020; Accepted 18-02-2020)
}

\begin{abstract}
The purpose of the current study was to determine the concentrations of adiponectin and testosterone in various ages of bucks as well as the correlations of adiponectin and testosterone with semen quality as an indicator of fertility. Nineteen Anglo Nubian (AN) x Etawah Grade (PE) (Anpera) crossbred bucks belonged to the Research Institute for Animal Production were classified into four different age groups: 24 months, 30 months, 36 months, and more than 48 months. The concentrations of adiponectin and testosterone in the samples of blood plasma were analyzed using enzyme-linked immunosorbent assay (ELISA). The semen characteristics were evaluated both macroscopically and microscopically. The results of the study showed that plasma concentrations of adiponectin in Anpera bucks at the ages of 24, 30, 36, and more than 48 months were $14.10 \pm 1.73 \mathrm{mg} / \mathrm{L}, 18.36 \pm 8.25$ $\mathrm{mg} / \mathrm{L}, 20.38 \pm 8.67 \mathrm{mg} / \mathrm{L}$, and $15.41 \pm 7.31 \mathrm{mg} / \mathrm{L}$, respectively. There was no significant difference in adiponectin concentrations among the age groups $(p>0.05)$. However, there were correlations of adiponectin concentrations with semen volume, sperm morphology, and sperm concentration. Plasma concentrations of testosterone at the ages of $24,30,36$, and more than 48 months were $9.76 \pm 2.46 \mathrm{ng} /$ $\mathrm{mL}, 9.81 \pm 1.56 \mathrm{ng} / \mathrm{mL}, 10.05 \pm 0.94 \mathrm{ng} / \mathrm{mL}$, and $9.93 \pm 2.71 \mathrm{ng} / \mathrm{mL}$, respectively. Plasma concentrations of testosterone in Anpera bucks also did not demonstrate a significant difference among the age groups $(p>0.05)$. However, plasma testosterone concentrations had significant correlations with semen volume, sperm motility, and sperm concentration. In conclusion, the plasma concentrations of adiponectin and testosterone hormones had correlations with the semen quality parameters, which are related to fertility.
\end{abstract}

Keywords: adiponectin; Anglo-Nubian crossbred; Etawah grade; fertility; testosterone

\section{INTRODUCTION}

The crossbreeding of Anglo-Nubian (AN) bucks and Etawah Grade (PE) does to create a new dairy-goat breed expected to be highly productive and adaptable to the tropical environment and climate. On the other hand, PE goats are crossbreds between local goats and Etawah goats from India which have been living in Indonesia for decades and have an advantage of high milk production (Sodiq, 2012; Dianingtyas et al., 2017). The crossbreeding was intended to increase production, but it was reported a decrease in fertility in males, such as a decrease in semen quality and libido in bull (Rajak et al., 2014). Therefore, an experiment is required to evaluate the fertility of crossbreed bucks.

The fertility of breeding male is influenced by the luteinizing hormone (LH) and follicle-stimulating hormone $(\mathrm{FSH})$ which modulate the synthesis of testosterone in Leydig cells and aromatase to estradiol synthesis in Sertoli cells. The hypothalamus-pituitarygonad (HPG) axis plays an important role in altering the secretions of gonadotropin and testosterone for spermatogenesis, sperm maturation, and reproductive behavior (Brito et al., 2007; Byrne et al., 2017). Therefore, the assessment of fertilities in breeding male is often conducted by measuring semen quality (Boe-Hansen et al., 2015), libido (Fahey et al., 2012), and the concentrations of testosterone hormone (Singh et al., 2014). Results from the most recent studies demonstrated that the protein hormone adiponectin had a positive correlation with fertility in bulls (Kasimanickam et al., 2013), sperm concentration and morphology in human (Thomas et al., 2013), and sperm motility in rams (Kadivar et al., 2016).

Adiponectin is a protein composed of 224 amino acids produced mainly by adipose tissues and some by bones and muscle tissues (Elfassy et al., 2018). Messenger ribonucleic acid (mRNA) for adiponectin has been found in the testicles and Leydig cells (Caminos 
et al., 2008) and in spermatocytes (Gregoraszczuk et al., 2016). Meanwhile, adiponectin has two receptors in binding with the cells, i.e., AdipoR1 and AdipoR2 (Elfassy et al., 2018). Adiponectin receptors are found in seminiferous tubules (Kasimanickam et al., 2013), Sertoli cells, Leydig cells, germinal cells (Kawwass et al., 2015), and sperm (Kasimanickam et al., 2013). Furthermore, Campos et al. (2008) stated that adiponectin had multiple roles and is pleiotropic since in addition to bind with its receptor, it could also interact with the other hormones to induce the target genes. Adiponectin works locally to increase sperm production to capacitation ability (Kasimanickam et al., 2013). It was reported that adiponectin concentration was higher in older bulls (>73 months) compared to the youngest bull $(<24-72$ months) (Heinz et al., 2015). However, a study in rats demonstrated a decline in adiponectin concentration when the rats were aging (Choubey et al., 2019). In addition, there is no report concerning the level of adiponectin in crossbreed bucks and its relations to the bucks fertility. Based on those findings, the present study was conducted to detect the concentration of adiponectin in AN x PE (Anpera) bucks and to determine its correlations with parameters of male fertility assessment to find a specific marker candidate in assessing the fertility of male bucks.

\section{MATERIALS AND METHODS}

\section{Ethical Statement}

The utilization of the treated animals in this study was ethically ratified by the Animal Care and Use Committee (ACUC) of IPB University, number: 81-2017 IPB.

\section{Animals}

The samples used in the present study were semen and blood samples collected from 19 Anpera bucks, with body weights range between 32 and $58 \mathrm{~kg}$ and aged range of 24-66 months old. The Anpera bucks belonged to the Research Institute for Animal Production and were raised in individual cages. The bucks were fed $3-4 \mathrm{~kg}$ of king grass and $0.5-0.7 \mathrm{~kg}$ of concentrate daily and water was available ad libitum. The bucks were classified into four age groups: 24 months old $(n=6)$, 30 months old $(n=6), 36$ months old $(n=4)$, and more than 48 months $(n=3)$. Observations of the libido, the collection and evaluation of semen, and the collection of blood samples from each animal were conducted in the morning; 5 times collections with an interval of 10 days, in line with the seminiferous epithelial cycle in bucks which was $10.6 \pm 0.5$ days (França et al., 1999). To obtain the same status, all animal samples were treated by semen collections one day before the first sample collection.

\section{Blood Collection and Processing}

Blood samples were collected from the jugular vein, with the volume ranging between 1.5 and $1.8 \mathrm{~mL}$ by us- ing a $3 \mathrm{~mL}$ disposable syringe filled with the anticoagulant ethylenediamine tetraacetic acidethylene diamine (EDTA) (Art. 8418 Titriplex® III, Merck, Darmstadt, Germany). The blood samples were then centrifuged at $5000 \mathrm{rpm}$ at room temperature for 10 minutes. The supernatant (blood plasma) was then poured into a microtube and stored at $-20^{\circ} \mathrm{C}$ until the analysis for adiponectin and testosterone concentrations.

\section{Measurements of Adiponectin Concentrations}

Adiponectin concentrations were measured by using goat adiponectin enzyme-linked immunosorbent assay (ELISA) kit produced by Bioassay Technology Laboratory, Shanghai Crystal Day Biotech Co., Ltd., China (Cat. No E0020GO). The measurements of adiponectin were performed by following the protocol in the instructions of the manufacturer. Briefly, $50 \mu \mathrm{L}$ of adiponectin standards were added to the standard wells and $40 \mu \mathrm{L}$ of the samples of blood plasma were placed in the sample wells. Ten $\mu \mathrm{L}$ of anti-adiponectin antibody and $50 \mu \mathrm{L}$ of streptavidin-horseradish peroxidase (HRP) were then added to the sample wells, standard well, and control well. The control well was only filled with $10 \mu \mathrm{L}$ of anti-adiponectin antibody and $50 \mu \mathrm{L}$ of streptavidinHRP. The filled plate was then thoroughly mixed, covered with a sealer, and incubated for 60 minutes at $37^{\circ} \mathrm{C}$. The sealer was removed and the plate was rinsed with a rinsing buffer 5 times. The wells were immersed in $0.35 \mathrm{~mL}$ of the rinsing buffer for 30 seconds to 1 minute for each rinsing. After rinsing, the wells were thumped firmly on the absorbent paper to remove any residual clumps. Substrates A and B $(50 \mu \mathrm{L})$ were added to each well, respectively. The plate was separated and covered using a new sealer for 10 minutes at $37^{\circ} \mathrm{C}$. The enzyme reaction was stopped by using $50 \mu \mathrm{L}$ of the stop solution. The absorbances (optical density) were measured by ELISA reader.

\section{Measurements of Testosterone Concentrations}

Testosterone concentrations were analyzed by using ELISA testosterone kit. The measurements of testosterone concentrations were done based on manual instruction from DRG diagnostic (Cat. no. EIA-1559, DRG Instruments $\mathrm{GmbH}$, Germany). Briefly, standard, control, and blood plasma samples $(25 \mu \mathrm{L})$, respectively, in duplicate were added into the appropriate wells on a microplate which were coated with testosterone monoclonal antibody. Subsequently, after adding 200 $\mu \mathrm{L}$ of enzyme conjugate each well was incubated for 60 minutes. The plates were then washed with washing solution and blotted dry four times. Then, each well was added $200 \mu \mathrm{L}$ of substrate solution (tetramethylbenzidine), and re-incubation was done for 15-20 minutes. All of the above procedures were conducted at room temperature. The enzyme reaction was stopped using $100 \mu \mathrm{L} 0.5 \mathrm{M} \mathrm{H}_{2} \mathrm{SO}_{4}$. The absorbance was measured at $450 \mathrm{~nm}$ using ELISA reader. 


\section{Libido Assessment}

The libido of the Anpera bucks were evaluated according to the method reported by Mickelsen et al. (1982). The libido was scored ranging from 0 to 10 . The score was score 0 , no interest; score 1 , interest only in one event; score 2, more than one interests one occurrence; score 3, active interest during the whole test period; score 4, one attempt to mount or mount, no intromission; score 5, two attempts to mount or mount, without intromission; score 6 , more attempts to mount or mount, no intromission; score 7 , one intromission, no interest anymore; score 8 , one intromission followed by interest; score 9, two intromissions, no interest anymore; score 10 , two intromissions followed by interest (including mounts and/or services).

\section{Semen Collection and Evaluation}

Semen samples were obtained from each animal and analyzed, as previously reported by Rodrigues et al. (2013) and Maidin et al. (2018). The semen samples were collected 5 times using an artificial vagina with 10 days interval, and measurement for the semen volume was used a tube with labels. Sperm motility, morphology, and concentration were evaluated under a microscope (Olympus, Tokyo, Japan). The collected semen was immediately placed in a water bath $\left(37^{\circ} \mathrm{C}\right)$ and evaluated for sperm motility, sperm morphology, and sperm concentration. The motility of sperm was evaluated subjectively, whereas the morphology and concentration of sperms were evaluated using eosin-nigrosin staining and Neubauer hemocytometer, respectively.

\section{Data Analysis}

The means of adiponectin and testosterone concentrations, libido scores, and semen quality were analyzed by one-way ANOVA, and probability of $p<0.05$ was determined as a significant difference. Furthermore, correlations between means of groups adiponectin and testosterone concentrations with the characteristics of semen were determined using Pearson's correlation test.

\section{RESULTS}

\section{The Plasma Concentrations of Adiponectin and Testosterone as well as the Libido in the Anpera Bucks}

The plasma concentrations of adiponectin in Anpera bucks at the ages of 24 months, 30 months, 36 months, and more than 48 months were $14.10 \pm 1.73$ $\mathrm{mg} / \mathrm{L}, 18.36 \pm 8.25 \mathrm{mg} / \mathrm{L}, 20.38 \pm 8.67 \mathrm{mg} / \mathrm{L}$, and $15.41 \pm 7.31$ $\mathrm{mg} / \mathrm{L}$, respectively (Figure 1 ). There was no significant difference in the plasma adiponectin concentrations among different ages of Anpera bucks ( $p>0.05)$.

On the other results, the plasma concentrations of testosterone in Anpera bucks also did not demonstrate a significant difference in the present study $(p>0.05)$. The plasma concentrations of testosterone in the bucks at the ages of $24,30,36$, and more than 48 months were
9.76 $\pm 2.46,9.81 \pm 1.56,10.05 \pm 0.94$, and $9.93 \pm 2.71 \mathrm{ng} / \mathrm{mL}$, respectively (Figure 2).

Based on the scores of libido, the present study also did not show a significant difference in the scores of libido among the different age groups of 24 months, 30 months, 36 months, and more than 48 months with an average score of $9.00 \pm 0.31,9.53 \pm 0.22,9.90 \pm 0.10$, and $9.07 \pm 0.48$, respectively ( $p>0.05$ ) (Figure 2 ).

\section{Correlations of Adiponectin and Testosterone with Semen Characteristics}

The semen characteristics in Anpera bucks for each of the age groups were presented in Table 1. Semen characteristics observed in the present study were semen volume, sperm concentration, sperm motility, and sperm morphology. No significant difference was found in the quality of semen evaluated among different age groups of Anpera bucks ( $p>0.05$ ).

Meanwhile, plasma adiponectin concentrations had a strong positive correlation with the semen volume $(\mathrm{p}<0.05)$, but no correlation was found with the sperm concentration and morphology $(\mathrm{p}>0.05)(\mathrm{r}=0.858-0.913)$, and a weak correlation with the sperm motility ( $\mathrm{r}=$ 0.394). Furthermore, testosterone concentration had positive and strong correlations with semen volume, sperm concentration and motility with a range of correlation coefficient $r=0.797-0.867$, and a weak correlation with sperm morphology ( $\mathrm{r}=0.317)$ (Table 2).

\section{DISCUSSION}

\section{The Plasma Concentrations of Adiponectin and Testosterone, and the Libido of Anpera Bucks}

The plasma concentrations of adiponectin in the current study showed no significant difference in Anpera bucks with different ages from 24 months to more than 48 months ( $>00.05)$. However, it seemed that there was an increase in the plasma concentrations of adiponectin in Anpera bucks from the ages of 24 months to 36 months, and the decreasing level of plasma concentrations of adiponectin in the animal ages more than 48 months. In contrast with our finding, Heinz et al. (2015) reported the older the age of the bulls, the higher the concentrations of adiponectin in the blood of the bull. It seemed that the pattern of concentrations

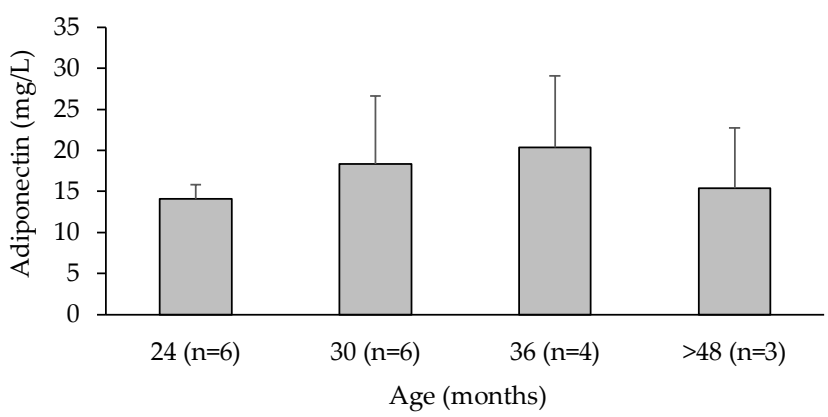

Figure 1. The plasma concentrations of adiponectin in Anpera bucks in various age groups. 

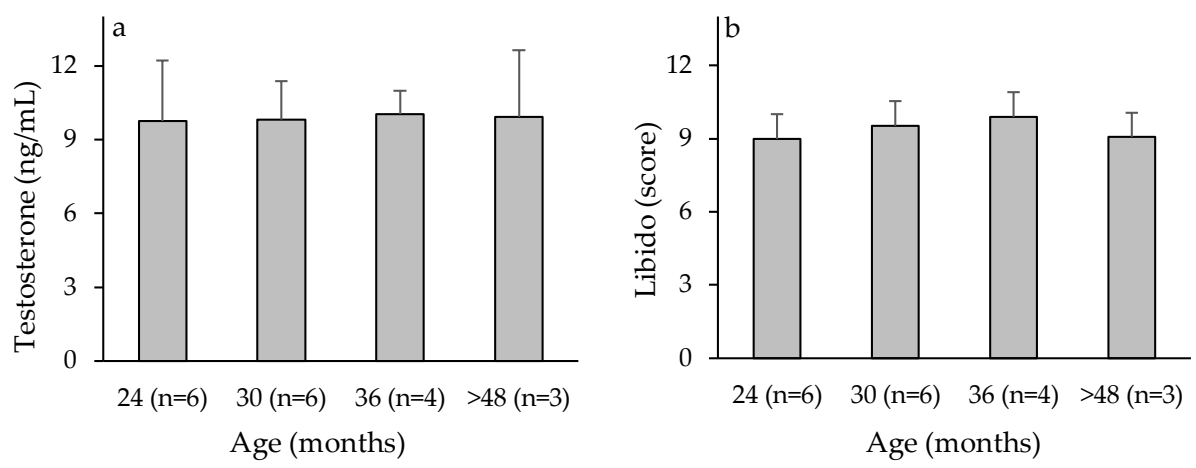

Figure 2. The plasma concentrations of testosterone (a) and libido score (b) in Anpera bucks in various age groups.

Table 1. Mean of semen characteristics in Anpera bucks in various ages (mean \pm SE)

\begin{tabular}{lcrrrr}
\hline \multirow{2}{*}{ Variables } & \multirow{2}{*}{ Replication } & \multicolumn{5}{c}{ Age (months) } \\
\cline { 3 - 6 } & & $24(\mathrm{n}=6)$ & $30(\mathrm{n}=6)$ & $36(\mathrm{n}=4)$ & $>48(\mathrm{n}=3)$ \\
\hline Semen volume $(\mathrm{mL})$ & 5 & $0.60 \pm 0.08$ & $0.78 \pm 0.05$ & $0.84 \pm 0.18$ & $0.75 \pm 0.03$ \\
Sperm concentration $\left(\mathrm{x} 10^{9} / \mathrm{mL}\right)$ & 5 & $2.05 \pm 0.23$ & $2.06 \pm 0.21$ & $2.52 \pm 0.27$ & $1.97 \pm 0.39$ \\
Sperm motility $(\%)$ & 5 & $76.92 \pm 1.72$ & $77.50 \pm 1.28$ & $79.75 \pm 1.18$ & $80.33 \pm 1.20$ \\
Sperm morphology $(\%)$ & 5 & $96.50 \pm 0.76$ & $98.03 \pm 0.40$ & $97.61 \pm 0.48$ & $96.60 \pm 0.24$ \\
\hline
\end{tabular}

Table 2 The correlation coefficient ( $\mathrm{r}$ ) between plasma adiponectin and testosterone concentrations with semen characteristics

\begin{tabular}{lcccc}
\hline \multirow{2}{*}{ Variables } & \multicolumn{4}{c}{ Correlation coefficient $(\mathrm{r})$} \\
\cline { 2 - 5 } & Semen volume & Sperm concentration & Sperm motility & Sperm morphology \\
\hline Adiponectin & $0.913^{*}$ & 0.858 & 0.394 & 0.879 \\
Testosterone & 0.799 & 0.797 & 0.867 & 0.317 \\
\hline
\end{tabular}

Note: ${ }^{*}=$ Correlation is significant at the 0.05 level.

of adiponectin in Anpera bucks in our study was in accordance with the pattern of adiponectin concentrations in rats reporting a decrease in the plasma concentration of adiponectin with the increase in the ages of rats (Choubey et al., 2019).

The older the animals, the adipose tissue will undergo hypertrophy with the result leading to the increase in adiponectin concentration in the blood and the increase in the sensitivity of adipose tissues to insulin (Cawthorn et al., 2012; Yu et al., 2019). Furthermore, Ayina et al. (2016) reported that the increase and decrease in adiponectin concentrations were determined by the factors of insulin resistance in the adipose tissues, intra-abdominal fat, and lipoprotein profile. A further report by Ting-Ting et al. (2019) stated that the increase in lipoprotein had a high correlation with the increase in age. Those statements were supported by Pfaehler et al. (2012), who reported that lipoprotein had a positive correlation with adiponectin concentration. It is proposed that the increase in adiponectin concentration follows the optimum reproductive age. According to Pezzanite et al. (2017), the optimum reproductive age for bucks and rams were up to four years. Therefore, the results of our study revealed a decrease in adiponectin concentration in the animal group for more than 48 months $(\mathrm{p}>0.05)$.

Further research in rats showed that old ages would decrease the plasma adiponectin concentration
(Lumeng et al., 2011). The decline in the plasma adiponectin concentration in the old-age mice was caused by the increase in insulin resistance (Cawthorn et al., 2012; Yu et al., 2019). The insulin resistance in the adipose tissues of animals was caused by the increased number of pro-inflammation macrophages due to aging (Lumeng et al., 2011), leading to a decline in plasma adiponectin concentration. Further proof was found in rats demonstrating a decline in plasma adiponectin concentration and receptors as the rats were in the aging phase (Choubey et al., 2019). Therefore, since there is no report on adiponectin pattern in old bucks, further research is required to explore the patterns of adiponectin in goats.

The plasma concentration of testosterone in Anpera bucks did not show a significant difference among age groups ( $>0.05)$ from age 24 months to more than 48 months in the current study. This finding was supported by the results reported by Hannan et al. (2017) that the plasma testosterone concentrations in post-pubertal age (34-52 weeks) significantly increased compared to earlylate pubertal age ( $<34$ weeks). Further study revealed that the plasma concentration of testosterone was associated with semen quality (Malik et al., 2018) so that the plasma concentrations of testosterone remained high during the period of active semen production. This condition was the reason why the plasma testosterone concentrations in our study were not significantly different among the age groups. Furthermore, all animal groups 
in our study could be categorized in the post-pubertal period and period of active in spermatogenesis. There is no report about the relationship between plasma testosterone concentration in Anpera bucks with different ages. Our study in Anpera bucks revealed that plasma testosterone concentrations had similarity to Kacang bucks (10.27 $\pm 5.42 \mathrm{ng} / \mathrm{mL}$ ) (Armansyah et al., 2018) and PE bucks (13.20 $\pm 3.96 \mathrm{ng} / \mathrm{mL})$ (Ferasyi et al., 2015).

Meanwhile, the pattern of libido scores in Anpera bucks had a similarity to the pattern of plasma testosterone concentrations. It is strongly suggested that testosterone primarily responsible for the maintenance of secondary sexual characteristics and libido (Hafez \& Hafez, 2000). A further study reported that libido was influenced by the presence of testosterone (Swelum et al., 2017).

\section{Correlations of Andiponectin and Testosterone with Semen Characteristics}

The results of our study showed that sperm production was not significantly different among the different age groups $(p>0.05)$. These results could be explained that the sperm production in mammals is strongly influenced by the number of Sertoli cells, and the formation of Sertoli cells is generally believed to be completed before pre-puberty (Berger, 2019). The results of our current study did not show a significant difference in the ages of Anpera bucks. A further reason for no difference in semen characteristics could be related to the influence of the months and the seasons (Elsheikh \& Elhammali, 2015).

According to El Kadili et al. (2019) the season factor was still more influential on the quality of semen in bucks. The reports of El Kadili et al. (2019) was strengthened by his finding that the highest quality of semen was obtained during summer and fall. It is therefore that semen collection during summer and fall would be more suitable for freezing than those during the other seasons.

Interestingly, the results of our current study revealed that adiponectin had a strong correlation with the concentration and morphology of sperm. These results are supported by Elfassy et al. (2018) that the concentration of adiponectin in seminal plasma has been shown to be positively correlated with sperm concentration, sperm count, and the percentage of typical sperm forms. These results indicate that adiponectin plays an important role in spermatogenesis.

These results were in line with a study on the morphology of sperm in cattle (Kasimanickam et al., 2013) and the concentration and morphology of sperm in humans (Thomas et al., 2013). In contrast, the results of the present study demonstrated that plasma testosterone concentration did not have a strong correlation with the morphology of sperm. Another study demonstrated that the normal morphology of sperm was more strongly influenced by genetic factors (Gotoh, 2010). This statement was proven that gene defects had a direct qualitative effect on sperm morphology or function (Ray et al., 2017).
Meanwhile, the results of our study revealed that plasma testosterone concentration had a strong positive correlation with sperm motility and concentrations. These results could be explained that testosterone did not only played a role in spermatogenesis but also in the formation of dense outer fibers in the sperm, which were important in the process that produces the motility of the sperm (Henkel et al., 2005). On the other side, adiponectin in our current results showed only a weak correlation with the motility of the sperm. This could be explained by the fact that the motility of sperm was influenced more strongly by a number of other proteins (Rodrigues et al., 2013), such as dehydrogenase subunit $\alpha$, phosphoglycerate mutase 2, and triose phosphate isomerase (Zhao et al., 2007).

Concerning to the positive correlation of testosterone with the sperm concentration, it is widely known that FSH and testosterone are key regulators of spermatogenesis. Each hormone plays a unique role in the differentiation and proliferation of spermatogonia, after which testosterone promotes the formation and differentiation of spermatocytes into round and elongated spermatids. Therefore, testosterone plays an important role in sperm concentration (Dickson \& Sanford, 2005). This role is played through the bonds between testosterone and Src and extracellular signal-regulated kinase (ERK), which facilitates the adhesion of germinal cells to Sertoli cells, which will then increase the release of immature sperm (Shupe et al., 2011).

In connection with the correlation with semen volume, both adiponectin and testosterone had a strong positive correlation with semen volume. In general, it is widely known that semen volume is influenced by the accessory glands, especially the seminal vesicle gland (Hafez \& Hafez, 2000). However, the synergistic relationship between adiponectin and testosterone with the activity of accessory glands, which has a large contribution to the volume of the semen, has not been known definitely (Goeritz et al., 2003). The results of the present study have strengthened the argument that adiponectin is a potential candidate as a parameter for male fertility assessment. However, further investigation with a greater number of samples and more uniform conditions is required.

\section{CONCLUSION}

The increase in the plasma adiponectin concentration in Anpera bucks is in accordance with the productive age and has a strong positive correlation with semen volume, sperm morphology, and sperm concentration. Meanwhile, plasma concentration of testosterone has a strong positive correlation with semen volume, sperm motility, and sperm concentrations.

\section{CONFLICT OF INTEREST}

The authors declare that there is no conflict of interests with any financial, personal, or other relationships with other people or organization related to the material discussed in the manuscript. 


\section{ACKNOWLEDGEMENT}

This study was funded by the Ministry of Research, Technology and Higher Education of The Republic of Indonesia, through Universitas Syiah Kuala under the project Doctoral Research Grant 2018 (Grant number: 18/UN11.2/PP/SP3/2018), and BPP-DN 2014. The author also wishes to acknowledge Research Institute for Animal Production for providing permission to use the experimental animals. Special appreciation goes to Dr. Gholib for his great assistances during this research.

\section{REFERENCES}

Armansyah, T., E. R. P. Barat, C. V. R. Handini, D. Aliza, A. Sutriana, H. Hamdan, B. Panjaitan, A. Sayuti, \& T. N. Siregar. 2018. Concentration and motility of spermatozoa and testosterone level of Kacang goat after seminal vesicle extract administration. Open. Vet. J. 8: 401-410. https://doi. org/10.4314/ovj.v8i4.9

Ayina, C. N. A., J. J. N. Noubiap, L. S. Etoundi Ngoa, P. Boudou, J. F. Gautier, M. K. Mengnjo, J. C. Mbanya, \& E. Sobngwi. 2016. Association of serum leptin and adiponectin with anthropomorphic indices of obesity, blood lipids and insulin resistance in a Sub-Saharan African population. Lipids. Health. Dis. 15: 96. https://doi.org/10.1186/ s12944-016-0264-x

Berger, T. 2019. Testicular estradiol and the pattern of Sertoli cell proliferation in prepuberal bulls. Theriogenology. 136: 60-65. https://doi.org/10.1016/j.theriogenology.2019.06.031

Boe-Hansen, G. B., J. P. A. Rego, J. M. Crisp, A. A. Moura, A. S. Nouwens, Y. Li, B. Venus, B. M. Burns, \& M. R. McGowan. 2015. Seminal plasma proteins and their relationship with percentage of morphologically normal sperm in 2-year-old Brahman (Bos indicus) bulls. Anim. Reprod. Sci. 162: 2030. https://doi.org/10.1016/j.anireprosci.2015.09.003

Brito, L. F., A. D. Barth, N. C. Rawlings, R. E. Wilde, D. H. Crews, P. S. Mir, \& J. P. Kastelic. 2007. Effect of improved nutrition during calfhood on serum metabolic hormones, gonadotropins, and testosterone concentrations, and on testicular development in bulls. Domest. Anim. Endocrin. 33: 460-469. https://doi.org/10.1016/j. domaniend.2006.09.004

Byrne, C. J., S. Fair, A. M. English, C. Urh, H. Sauerwein, M. A. Crowe, P. Lonergan, \& D. A. Kenny. 2017. Effect of breed, plane of nutrition and age on growth, scrotal development, metabolite concentrations and on systemic gonadotropin and testosterone concentrations following a GnRH challenge in young dairy bulls. Theriogenology. 96: 58-68. https://doi.org/10.1016/j.theriogenology.2017.04.002

Caminos, J. E., R. Nogueiras, F. Gaytán, R. Pineda, C. R. González, M. L. Barreiro, J. P. Castaño, M. M. Malagón, L. Pinilla, J. Toppari, C. Diéguez, \& M. Tena-Sempere. 2008. Novel expression and direct effects of adiponectin in the rat testis. Endocrinology. 149: 3390-3402. https://doi. org/10.1210/en.2007-1582

Campos, D. B., M. F. Palin, V. Bordignon, \& B. D. Murphy. 2008. The 'beneficial' adipokines in reproduction and fertility. Int. J. Obes. 32: 223-231. https://doi.org/10.1038/ sj.ijo.0803719

Cawthorn, W. P., E. L. Scheller, \& O. A. MacDougald. 2012. Adipose tissue stem cells meet preadipocyte commitment: going back to the future. J. Lipid. Res. 53: 227-246. https:// doi.org/10.1194/jlr.R021089

Choubey, M., A. Ranjan, P. S. Bora, F. Baltazar, L. J. Martin, \& A. Krishna. 2019. Role of adiponectin as a modulator of testicular function during aging in mice. Biochim. Biophys. Acta. 1865: 413-427. https://doi.org/10.1016/j. bbadis.2018.11.019

Dianingtyas, B. D., Y. Retnani, \& D. Evvyernie. 2017. Legume wafer supplementation to increase the performance of post-weaning Etawah grade goats. Med. Pet. 40: 42-46. https://doi.org/10.5398/medpet.2017.40.1.42

Dickson, K. A., \& L. M. Sanford. 2005. Breed diversity in FSH, $\mathrm{LH}$ and testosterone regulation of testicular function and in libido of young adult rams on the southeastern Canadian prairies. Small. Rumin. Res. 56: 189-203. https:// doi.org/10.1016/j.smallrumres.2004.06.002

El Kadili, S., M. Raes, J. L. Bister, B. Archa, M. Chentouf, \& N. Kirschvink. 2019. Effect of season on sexual behavior, testicular measurements and seminal characteristics in "Beni Arouss" North Moroccan bucks. Anim. Reprod. Sci. 201: 41-54. https://doi.org/10.1016/j.anireprosci.2018.12.007

Elfassy, Y., J.-P. Bastard, C. McAvoy, S. Fellahi, J. Dupont, \& R. Levy. 2018. Adipokines in semen: physiopathology and effects on spermatozoas. Int. J. Endocrinol. 2018: 1-11. https://doi.org/10.1155/2018/3906490

Elsheikh, A. S., \& N. S. Elhammali. 2015. Semen quality of mature crossbred male goats during different seasons. IOSRJAVS. 8: 1-5.

Fahey, A., P. Duffy, \& S. Fair. 2012. Effect of exposing rams to a female stimulus before semen collection on ram libido and semen quality. J. Anim. Sci. 90: 3451-3456. https://doi. org/10.2527/jas.2011-4859

Ferasyi, T. R., M. Akmal, B. Hamdani, Razali, Azhari, S. Wahyuni, Amiruddin, Anwar, F. A. Pamungkas, S. Nasution, \& R. A. Barus. 2015. Potency of combination of palm kernel meal and katuk leaf powder to improve the production performance of Peranakan Etawa (PE) goat: toward a strategy for quality control of meat using "CGE" concept. Procedia. Food. Sci. 3: 389-395. https://doi. org/10.1016/j.profoo.2015.01.043

França, L., S. Becker-Silva, \& H. Chiarini-Garcia. 1999. The length of the cycle of seminiferous epithelium in goats (Capra hircus). Tissue Cell. 31: 274-280. https://doi. org/10.1054/tice.1999.0044

Goeritz, F., M. Quest, A. Wagener, M. Fassbender, A. Broich, T. B. Hildebrandt, R. R. Hofmann, \& S. Blottner. 2003. Seasonal timing of sperm production in roe deer: interrelationship among changes in ejaculate parameters, morphology and function of testis and accessory glands. Theriogenology. 59: 1487-1502. https://doi.org/10.1016/ S0093-691X(02)01201-3

Gotoh, H. 2010. Inherited sperm head abnormalities in the B10.M mouse strain. Reprod. Fertil. Dev. 22: 1066-1073. https://doi.org/10.1071/RD09295

Gregoraszczuk, E., M. Slupecka, J. Wolinski, A. Hejmej, B. Bilinska, E. Fiedor, N. Piwnicka, \& A. Rak. 2016. Maternal high-fat diet during pregnancy and lactation had gender difference effect on adiponectin in rat offspring. J. Physiol. Pharmacol. 67: 543-553.

Hafez, E. S. E., \& B. Hafez. 2000. Reproduction in Farm Animals. 7th edition. Lippincott Williams \& Wilkins, Philadelphia (US). https://doi.org/10.1002/9781119265306

Hannan, M. A., N. Kawate, Y. Fukami, W. W. P. N. Weerakoon, E. E. Büllesbach, T. Inaba, \& H. Tamada. 2017. Changes of plasma concentrations of insulin-like peptide 3 and testosterone, and their association with scrotal circumference during pubertal development in male goats. Theriogenology. 92: 51-56. https://doi.org/10.1016/j. theriogenology.2017.01.009

Heinz, J. F., S. P. Singh, U. Janowitz, M. Hoelker, D. Tesfaye, K. Schellander, \& H. Sauerwein. 2015. Characterization of adiponectin concentrations and molecular weight forms in serum, seminal plasma, and ovarian follicular 
fluid from cattle. Theriogenology. 83: 326-333. https://doi. org/10.1016/j.theriogenology.2014.06.030

Henkel, R., G. Maass, H. C. Schuppe, A. Jung, J. Schubert, \& W. B. Schill. 2005. Molecular aspects of declining sperm motility in older men. Fertil. Steril. 84: 1430-1437. https:// doi.org/10.1016/j.fertnstert.2005.05.020

Kadivar, A., H. H. Khoei, H. Hassanpour, A. Golestanfar, \& H. Ghanaei. 2016. Correlation of adiponectin mRNA abundance and its receptors with quantitative parameters of sperm motility in rams. Int. J. Fertil. Steril. 10: 127.

Kasimanickam, V. R., R. K. Kasimanickam, J. P. Kastelic, \& J. S. Stevenson. 2013. Associations of adiponectin and fertility estimates in Holstein bulls. Theriogenology. 79: 766-777. https://doi.org/10.1016/j.theriogenology.2012.12.001

Kawwass, J. F., R. Summer, \& C. B. Kallen. 2015. Direct effects of leptin and adiponectin on peripheral reproductive tissues: a critical review. Mol. Hum. Reprod. 21: 617-632. https://doi.org/10.1093/molehr/gav025

Lumeng, C. N., J. Liu, L. Geletka, C. Delaney, J. Delproposto, A. Desai, K. Oatmen, G. Martinez-Santibanez, A. Julius, S. Garg, \& R. L. Yung. 2011. Aging is associated with an increase in T cells and inflammatory macrophages in visceral adipose tissue. J. Immunol. 187: 6208-6216. https:// doi.org/10.4049/jimmunol.1102188

Maidin, M. S., M. Padlan, S. Azuan, R. Jonit, N. Mohammed, \& R. Abdullah. 2018. Supplementation of Nigella sativa oil and honey prolong the survival rate of fresh and postthawed goat sperms. Trop. Anim. Sci. J. 41: 94-99. https:// doi.org/10.5398/tasj.2018.41.2.94

Malik, M. I., H. Jamil, Z. I. Qureshi, A. Mehfooz, S. N. B. Rizvi, S. Ullah, S. R. Dilshad, A. Zaman, N. Ullah, \& S. K. Safdar. 2018. Investigation on relationship of hormonal profile and biochemical constituents of seminal plasma with physical characteristics of Damani buck semen. Pure. Appl. Biol. 7: 684-691.

Mickelsen, W. D., L. G. Paisley, \& J. J. Dahmen. 1982. The relationship of libido and serving capacity test scores in rams on conception rates and lambing percentage in the ewe. Theriogenology. 18: 79-86. https://doi. org/10.1016/0093-691X(82)90051-6

Pezzanite, L., A. Bridges, M. Nearly, \& T. Hutchens. 2017. Breeding Soundness Examination of Rams and Bucks. Purdue University Cooperative Extension Service, West Lafayette (US).

Pfaehler, A., M. K. Nanjappa, E. S. Coleman, M. Mansour, D. Wanders, E. P. Plaisance, R. L. Judd, \& B. T. Akingbemi. 2012. Regulation of adiponectin secretion by soy isoflavones has implication for endocrine function of the testis. Toxicol. Lett. 209: 78-85. https://doi.org/10.1016/j. toxlet.2011.11.027

Rajak, S. K., A. Kumaresan, M. K. Gaurav, S. S. Layek, T. K. Mohanty, M. K. M. Aslam, U. K. Tripathi, S. Prasad, \&
S. De. 2014. Testicular cell indices and peripheral blood testosterone concentrations in relation to age and semen quality in crossbred (Holstein Friesian $\times$ Tharparkar) bulls. Asian-Australas. J. Anim. Sci. 27: 1554-1561.https://doi. org/10.5713/ajas.2014.14139

Ray, P. F., A. Toure, C. Metzler-Guillemain, M. J. Mitchell, C. Arnoult, \& C. Coutton. 2017. Genetic abnormalities leading to qualitative defects of sperm morphology or function. Clin. Genet. 91: 217-232. https://doi.org/10.1111/cge.12905

Rodrigues, M., C. Souza, J. Martins, J. Rego, J. Oliveira, G. Domont, F. Nogueira, \& A. Moura. 2013. Seminal plasma proteins and their relationship with sperm motility in Santa Ines rams. Small. Rumin. Res. 109: 94-100. https:// doi.org/10.1016/j.smallrumres.2012.07.032

Shupe, J., J. Cheng, P. Puri, N. Kostereva, \& W. H. Walker. 2011. Regulation of Sertoli-Germ cell adhesion and sperm release by FSH and nonclassical testosterone signaling. Mol. Endocrinol. 25: 238-252. https://doi.org/10.1210/ me.2010-0030

Singh, A., P. Brar, \& R. Cheema. 2014. Relationships among frozen-thawed semen fertility, physical parameters, certain routine sperm characteristics and testosterone in breeding Murrah buffalo (Bubalus bubalis) bulls. Vet. World. 7: 644651.https://doi.org/10.14202/vetworld.2014.644-651

Sodiq, A. 2012. Non genetic factors affecting pre-weaning weight and growth rate of Etawah grade goats. Med. Pet. 35: 21. https://doi.org/10.5398/medpet.2012.35.1.21

Swelum, A. A.-A., I. M. Saadeldin, H. A. Zaher, S. A. M. Alsharifi, \& A. N. Alowaimer. 2017. Effect of sexual excitation on testosterone and nitric oxide levels of water buffalo bulls (Bubalus bubalis) with different categories of sexual behavior and their correlation with each other. Anim. Reprod. Sci. 181: 151-158. https://doi.org/10.1016/j. anireprosci.2017.04.003

Thomas, S., D. Kratzsch, M. Schaab, M. Scholz, S. Grunewald J. Thiery, U. Paasch, \& J. Kratzsch. 2013. Seminal plasma adipokine levels are correlated with functional characteristics of spermatozoa. Fertil. Steril. 99: 1256-1263. e1253. https://doi.org/10.1016/j.fertnstert.2012.12.022

Ting-Ting, W., Z. Ying-Ying, Y. Yi-Ning, L. Xiao-Mei, M. YiTong, \& X. Xiang. 2019. Age, sex, and cardiovascular risk attributable to lipoprotein cholesterol among Chinese individuals with coronary artery disease: a case-control study. Metab. Syndr. Relat. Disord. 17: 223-231. https://doi. org/10.1089/met.2018.0067

Yu, P., R. Yuan, X. Yang, \& Z. Qi. 2019. Adipose tissue, aging, and metabolism. Curr. Opin. Endocr. Metab. Res. 5: 11-20. https://doi.org/10.1016/j.coemr.2019.02.003

Zhao, C., R. Huo, F. Q. Wang, M. Lin, Z. M. Zhou, \& J. H. Sha. 2007. Identification of several proteins involved in regulation of sperm motility by proteomic analysis. Fertil. Steril. 87: 436-438. https://doi.org/10.1016/j.fertnstert.2006.06.057 